https://helda.helsinki.fi

Social learning as a link between the individual and the collective: evaluating deliberation on social values

\title{
Eriksson, Max
}

2019-09

Eriksson, M , van Riper , C J , Leitschuh , B , Bentley Brymer , A, Rawluk , A, Raymond , C M \& Kenter , J O 2019 , ' Social learning as a link between the individual and the collective: evaluating deliberation on social values ', Sustainability Science, vol. 14 , no. 5 , pp. 1323-1332 . https://doi.org/10.1007/s11625-019-00725-5

http://hdl.handle.net/10138/318566

https://doi.org/10.1007/s11625-019-00725-5

unspecified

acceptedVersion

Downloaded from Helda, University of Helsinki institutional repository.

This is an electronic reprint of the original article.

This reprint may differ from the original in pagination and typographic detail.

Please cite the original version. 
Running Head: Learning from deliberation on social values

\title{
Social learning as a link between the individual and the collective: Evaluating deliberation
} on social values

\author{
Max Eriksson ${ }^{1}$ \\ Carena J. van Riper ${ }^{1+}$ \\ Ben Leitschuh ${ }^{1}$ \\ Amanda Bentley Brymer ${ }^{2}$ \\ Andrea Rawluk ${ }^{3}$ \\ Christopher M. Raymond ${ }^{4,5,6}$ \\ Jasper O. Kenter ${ }^{7}$ \\ ${ }^{1}$ Department of Natural Resources and Environmental Sciences, University of Illinois \\ ${ }^{2}$ Environmental Science Program, University of Idaho \\ ${ }^{3}$ University of Melbourne \\ ${ }^{4}$ Helsinki Institute of Sustainability Science, University of Helsinki, Finland \\ ${ }^{5}$ Ecosystems and Environment Research Program, Faculty of Biological and Environmental \\ Sciences, University of Helsinki \\ ${ }^{6}$ Department of Environmental and Resource Economics, Faculty of Agriculture and Forestry, \\ University of Helsinki \\ ${ }^{7}$ Department of Environment and Geography, University of York, United Kingdom
}

${ }^{+}$Corresponding author

Department of Natural Resources and Environmental Sciences

University of Illinois at Urbana-Champaign

1102 S. Goodwin Ave.

Urbana, IL, U.S.A., 61801

Email: cvanripe@illinois.edu

Phone: 217-244-9317

Published in Sustainability Science.

Eriksson, M., van Riper, C.J., Leitschuh, B., Bentley-Brymer, A., Rawluk, A., Raymond, C., \& Kenter, J. (2019). Social learning as a link between the individual and the collective: Evaluating deliberation on social values. Sustainability Science, 14(5), 1323-1332. 


\begin{abstract}
The role of social learning in deliberative processes is an emerging area of research in sustainability science. Functioning as a link between the individual and the collective, social learning has been envisioned as a process that can empower and give voice to a diverse set of stakeholder viewpoints, contribute to more adaptive and resilient management decisions and foster broader societal transformations. However, despite its widespread use in the context of participatory management of natural resources, the empirical properties of social learning remain understudied. This paper evaluates the role of social interaction and social capital to achieve transformative learning in discussions about social values. We employ a longitudinal design involving three consecutive surveys of 25 participants of an expert workshop focused on social values, as well as approximately 12 hours of transcribed audio and video recordings of participant interactions. Our mixed methods approach demonstrates the potential of using changes in social networks and definitions of social values that emerge from qualitative coding as indicators of social learning. We find that individuals with a weaker conceptual understanding of social values are more likely to change their definitions of the concept after deliberation. Though slight, these changes display a shift towards definitions more firmly held by other group members.
\end{abstract}




\section{Introduction}

Over the past two decades, scholarship on transdisciplinary, community-based involvement in management decisions has burgeoned in co-management and knowledge coproduction literatures (Armitage et al., 2011; Cundill \& Rodela, 2012; Kates et al., 2001; Medema et al., 2016; Reyers et al., 2015). More inclusive management practices and governance systems are perceived as having a normative value, as they empower marginalized stakeholder groups and facilitate direct citizen participation in public processes (Culwik et al., 2019; Kenter et al., 2016; Liu et al., 2007; Ostrom, 1990, 2009). Increased public participation and inclusive deliberation confer a wide range of benefits, such as the ability to find novel solutions to recurring problems, the improved ability to turn scientific information into actionable knowledge relevant for policy action, increased legitimacy for institutions involved in resource management, and building a mutual understanding and ownership of results among participants (Baber \& Bartlett, 2005; Cash et al., 2003; Culwick et al., 2019; Frantzeskaki \& Kabisch, 2016; Lundmark et al., 2014). These societal trends are supported by a growing body of research in natural resource management and sustainability sciences that has called for clearer and more coherent understandings of the processes and outcomes of social learning (Muro \& Jeffrey, 2008; Reed et al., 2010; Rodela, 2011; Wal et al., 2014).

A breadth of definitions and approaches have been applied to analyze the role of social learning in deliberative processes. The common core of many definitions is that individuals learn through engagement with others, which is situated in a wider social setting (Reed et al., 2010). However, this conceptualization of social learning does not capture the full complexity of influences that ultimately guide human behavior (Merriam \& Caffarella, 1998). Some researchers have emphasized the potential of social learning as a tool to achieve collective-level 
social change (Pascual et al., 2017; Rist et al., 2007; Steyaert \& Jiggins, 2007; Webler et al., 1995). A debate on whether social learning should be understood as a process or an outcome is also prominent in the sustainability science literature (Collins \& Ison, 2009), and there are related discussions on whether social learning is a linear process on the individual level (Umemoto \& Suryanata, 2006), or if it is more accurately described as a collective-level emergent phenomenon resulting from the sum of all individual interactions (Daniell et al., 2010) or a multi-level process (Diduck et al., 2019).

While varied conceptualizations, characterizing features, levels of analysis, and operational measures of social learning exist across individual-, network-, and systems-centric research perspectives (Rodela, 2011), few researchers have operationalized social learning nor addressed what counts as proof of learning (Rodela, 2013). Recently, Bentley Brymer et al. (2018) synthesized dimensions and variables of social learning commonly found in the literature and developed a framework to analyze social learning at an individual level. Previous research in psychology that suggests verbal inquiry between conversational agents creates opportunities for learning (Graesser et al., 1993, 2014). As a corollary, Bentley Brymer et al. (2018) established a promising framework for better understanding and empirically investigating how learning occurred through deliberation among individuals. These authors also acknowledged that changes in understanding also occur through social interactions and become situated within wider communities of practice (Reed et al., 2010).

Social learning is a cornerstone of deliberative democracy given that individual and collective-level learning is conducive to the development and implementation of policies that reflect an inclusive set of stakeholder viewpoints (Folke et al., 2005; Goodin, 2017; Pahl-Wostl et al., 2007; Kenter et al. 2016a, 2016b). Deliberation facilitates a discovery of shared values and 
the development of new values that emerge from in-depth exchanges (Schulser et al., 2003;

Reich, 1985; van Riper et al., 2018), as well as communication within a social setting that results from relational understandings of an environment (Chan et al., 2018; Gould et al., 2019;

McCrum et al., 2019). Despite previous efforts to clarify the mechanisms through which social learning occurs (e.g., Schusler et al, 2003; Van der Wal et al., 2014; Vinke-de Kruijf, \& PahlWostl, 2016), the processes within deliberative contexts that move people from seeing oneself as an isolated individual to seeing oneself as part of a collective are still unknown (Cundill \& Rodela, 2012). Social capital theory (see Putnam, 2000; Bourdieu, 1986) has also been identified as important to the process and outcomes of social learning (Cundill \& Rodela, 2012; Muro \& Jeffrey, 2008). Social capital theory's focus on trust within groups, reciprocity, social interaction, group norms, and interconnectedness can bring clarity to the role of social learning in relation to the individual and her social context. Scholars within sustainability science have therefore underscored the importance of increased engagement in decision-making and transformative change attributable to the process and outcomes of deliberation (Goodin \& Niemeyer, 2003; Pellizzoni, 2001; Rodela, 2013; Kenter et al. 2016a, 2016b).

In combination, the literatures related to social learning, social values and social capital are likely to advance conceptualization of the mechanisms behind social learning, as well as bring other useful insights to adaptive and co-adaptive management literatures (Armitage et al., 2011; Berkes, 2009; Dietz et al., 2003; Hahn et al., 2008). Social network theory is a common thread in these literatures; it shows potential to clarify the relationship among individuals and between individuals and a social context. Previous scholarship has theorized that social learning contributes to the creation and maintenance of stakeholder networks (Rodela, 2011; Steyaert \& Jiggins, 2007) and that most new knowledge is created among loosely connected members 
(Fischer et al., 2014; Granovetter, 1973; Levin \& Cross, 2004; Prell et al., 2009). In particular, individuals with weak ties to other people facilitate social learning and these ties therefore bridge clusters of people within networks (Granovetter, 1973). Networks comprised of well-connected individuals (i.e., networks with a large proportion of strong ties) provide a foundation for building social capital given that they foster trust and social norms, and contribute to the spread of social values. Therefore, learning is most likely to occur in networks that strike a balance between weak and strong ties (Burt, 2004; McPherson \& Smith-Lovin, 1987).

Another area of inquiry that carries potential to advance knowledge of social learning is the social values literature (Chan et al., 2012; Dietsch et al., 2016; Kenter et al., 2019; Raymond et al., 2014; van Riper \& Kyle, 2014), including core principles that guide behavior (Rokeach, 1973; Schwartz, 1994; van Riper et al., 2019), economic and non-economic landscape preferences (Brown, 1984; Brown \& Kytta, 2014), felt and relational values (Schroeder, 2013; Chan et al., 2016), and indicators of shared, social values (Kenter et al., 2015; Rawluk et al., 2019). The social values and social learning lines of research are complementary, because values are integral to deliberative processes (Dietz, 2013), and deliberative processes have been identified as drivers of value change (Raymond \& Kenter, 2016). Recent empirical research on non-market, deliberative valuation highlights that deliberation can lead to a statistically significant convergence in preferences, in that social learning can shape individual viewpoints to align with the views of a collective (Grainger \& Stoeckl, 2019). Although group deliberation and social learning may affect the rate of change among value concepts (Kendal \& Raymond, 2019; Manfredo et al., 2017; van Riper et al., 2018), the long-term effects of deliberation on social values remain largely unclear (Goodin \& Niemeyer, 2003; Kenter et al., 2016b; Pellizzoni, 2001). 
In this study, we investigate social learning that occurred among individuals and across an international group of experts before, during and after their deliberation on the concept of social values. We advance the social values literature by demonstrating how social learning can lead to more a nuanced understanding of social values for sustainability, improved interconnections among scholars and knowledge of different disciplinary positions on values theory. The following objectives guided our research design: 1) Document variation and change in definitions of social values among workshop participants; 2) Quantify and classify participants' social interactions about social values; and 3) Determine how interconnectedness, similarities in academic background, definitions of social values, and social interaction relate to social learning. In the following section, we describe our data collection process and methods, including a detailed presentation of an analytical framework based on academic background, definitions of social values and social interaction. Finally, we discuss how variation in individual traits affect social learning at the individual and group levels.

\section{Methodology}

\section{Study area and design}

This paper showcased a mixed methods approach for measuring social learning by drawing on survey data and qualitatively coded transcripts from an academic workshop focused on social values and environmental sustainability named "Theoretical Traditions in Social Values for Sustainability" held at the University of York, UK, 26-27th June 2018 (Raymond et al., 2018). This workshop included authors of the papers in this Special Feature (Kenter et al., 2019) and was funded by the United Kingdom Valuing Nature Programme. All attendees were asked to participate in three online surveys that measured background information, potential changes in social learning and definitions of social values as a result of workshop participation. 
The surveys were distributed one week prior to the workshop (Survey 1), two weeks after the workshop (Survey 2), and three months after the workshop (Survey 3). We also employed social network analysis to study how instances of social learning, defined as a process of individual learning that happens in a social context (Bandura, 1977, 2018), could be identified as the product of social interaction and capital. This information was then used as the basis for a social network analysis (Scott, 1988), in which each individual respondent was treated as a node, with edges signifying cases where two respondents both indicated that another person was a previous acquaintance in Survey 1, or noted the other person was a collaborator in either Survey 2 or Survey 3. Variables related to academic background were considered to be evidence of social capital, while changes in the definitions of social values and social interactions during the workshop were used as evidence of social learning.

\section{Measurements}

The first of three surveys administered contained two open-ended questions designed to measure respondent backgrounds: "What is your primary academic discipline?" and "How many years have you been working on research questions related to social values for sustainability?" The academic fields of participants were categorized into larger thematic groups, and the question about previous research experience was recoded into 5 bins: >1, 1-3, 4-6, 7-9, and 10 years. Two items were used to assess respondents' definitions of social values, including "How do you define the concept of social values?" and "Under what circumstances would social values change?" A review of existing literature on social learning and typological analysis was used to identify the most salient variations in respondents' viewpoints relating to social values, with particular attention on the level of operation(s), mechanisms, and outcomes of different kinds of 
social learning. Also, the question "Of the workshop participants, with whom have you previously collaborated" was used to measure interconnectedness.

In the second and third surveys, to measure social interaction, the following questions were added to the survey: "Did you make any new acquaintances that are likely to lead to new research collaborations during this workshop? If so, which new acquaintances, and what new collaborations could emerge from them?" and "Are you planning to initiate any new research collaborations as a result of the workshop, if so with which participants?" Survey items related to collaboration were coded to signify whether respondents reported previous collaborative experiences with other workshop participants before the meeting or had formed any new collaborations after the in-person meeting.

To complement the longitudinal survey data collected from workshop participants, all group conversations in formal settings during the workshop were video and audio recorded. All recordings were transcribed verbatim to understand interactions among the workshop participants (Guest et al., 2012), and the transcripts were then coded using open and axial coding (Marshall \& Rossman, 2006). Specifically, question-answer exchanges among participants were identified and treated as proxies for social interaction. Each question and answer exchange was then classified as either "cognitive" (i.e.., reflecting knowledge of facts and values; identification of factors contributing to a problem), "relational" (i.e., reflecting perceptions of others; expressions of trust; identification of opportunities for collaboration), or "epistemic" (i.e., challenging ways of knowing; questioning claims of validity; justification for knowledge), following Bentley Brymer et al. (2018) (see Table 1). 
Table 1. Definitions of social learning dimensions drawn from Bentley Brymer et al. (2018)

\begin{tabular}{ll}
\hline $\begin{array}{l}\text { Dimension of social } \\
\text { learning }\end{array}$ & Operationalization \\
\hline Cognitive & $\begin{array}{l}\text { Knowledge of facts and values; identification of factors contributing } \\
\text { to a problem }\end{array}$ \\
Relational & $\begin{array}{l}\text { Perceptions of others; expressions of trust; identification of } \\
\text { opportunities for collaboration } \\
\text { Challenging ways of knowing; questioning claims of validity; } \\
\text { Epistemic }\end{array}$ \\
\hline
\end{tabular}

\section{Results}

A total of 25 individuals attended the Valuing Nature Programme workshop. Out of these, 21 completed Survey 1, seven completed Survey 2, and ten completed Survey 3. The total length of the workshop recordings was approximately 12 hours, which amounted to 320 pages of text that was transcribed verbatim and thematically analyzed. A majority of the 19 participants that answered the question about academic field were academics with interdisciplinary backgrounds related to conservation. Based on their answers, we categorized respondents into four groups: 1) Economics $(n=6) ; 2)$ Environmental Science $(n=5) ; 3)$ Psychology and Health $(n=3)$; and 4) Other Social Sciences $(n=5)$ (see Appendix 1).

Twenty respondents provided their definitions of social values in response to the question, "How do you define the concept of social values?" in the first survey. The majority of definitions emphasized that social values arise from processes occurring at the group $(n=12)$ or societal levels $(\mathrm{n}=10)$. For example, participants defined social values as "values that are beyond individual values and preferences," and "values shared with others and society in general." Out of the 20 definitions reported, the primary mechanism to catalyze the spread of social values was social context, relational interactions and mutual experience developed and expressed through relationships. Definitions also emphasized the importance of coexistence, as illustrated by one participant who defined social values as "values held by both individuals and collectives and 
play some role in living harmoniously with others." Changes in thoughts and practice, providing benefits for others and meeting popular needs were also cited as outcomes of deliberative processes surrounding social values.

In Survey 2, three respondents stated that they had changed their definition of social values as a result of the workshop. One person indicated that the workshop "clarified how other people use the term," while another asserted that they had "developed a more pluralist or holistic definition of social values following the workshop." Another participant stated, "it enhanced my depth of understanding - seeing different ways of understanding social values as lenses by which we look at common issues." In Survey 3, the question "How do you define the concept of social values?" was repeated, but the differences in definitions compared to Survey 1 were slight. An overview of variation across definitions is presented in Table 2 and full definitions and codes are available in Appendix 1, Table 2.

Table 2. Definitions of social values among workshop participants

\begin{tabular}{lll}
\hline Aspect of social values & Focus of definition provided & N \\
\hline \multirow{3}{*}{ Level of operation(s) } & Individual level & 5 \\
& Group level & 15 \\
& Societal level & 2 \\
Mechanism & Relational & 4 \\
& Similar experiences & 1 \\
& Social context & 5 \\
Outcome & Coexistence & 2 \\
& Changes in thoughts and practice & 2 \\
\multirow{2}{*}{ Changes of definitions } & Meeting needs & 2 \\
& Benefiting others & 1 \\
& Between Survey 1 and Survey 2 & 3 \\
\hline
\end{tabular}


We observed 95 question-answer exchanges throughout the workshop dialogue.

Cognitive question-answer exchanges $(n=63)$ were most common, including requests to clarify established concepts and their definitions. A total of 19 relational question-answer exchanges were observed at the workshop. Epistemic question-answer exchanges $(n=13)$ occurred when concepts were the subject of interdisciplinary synthesis and growth and were thus unclear and/or contested. In these cases, questions were framed as requests for evidence in support of knowledge claims. All exchanges that were observed, varied in length and complexity with longer discussions often involving individuals that presented the results of a discussion group or led a session.

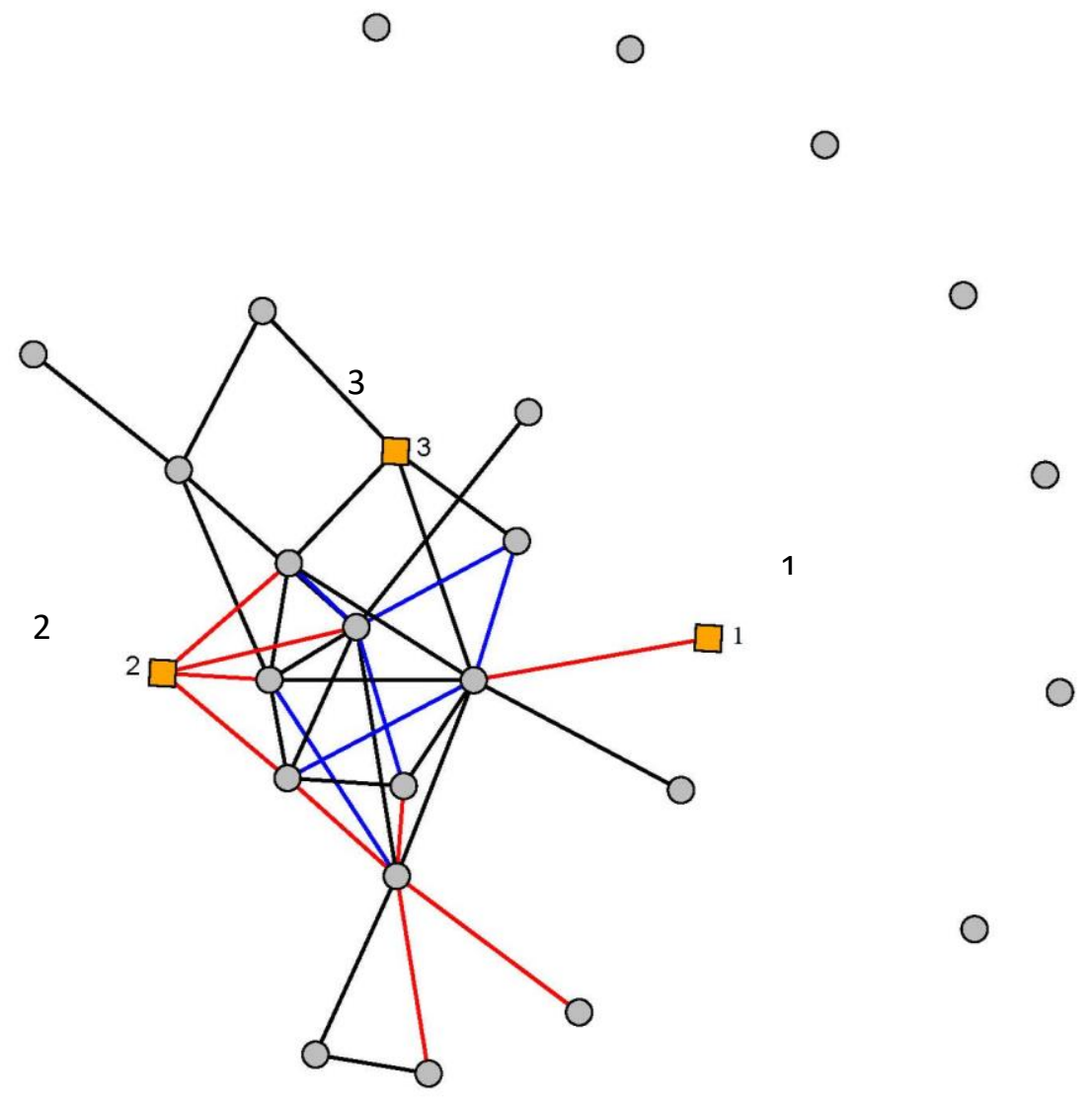

Figure 1. Collaborations among the 28 participants in the Valuing Nature Programme workshop 
A total of 18 individuals had collaborated with another participant before the workshop (see Table 3). Survey 2 indicated that there were five new potential collaborations immediately after the workshop, and in Survey 3, six more collaborative opportunities were noted. Eight participants did not report any collaborations with other participants throughout the three surveys. In Figure 1, workshop participants were illustrated as nodes in a network and collaborations between participants as connection between these nodes. The workshop participants were represented by gray circles, while the three participants that changed their definitions of social values between Survey 1 and Survey 2 were shown as orange squares. Collaborations reported in Survey 1 were represented by black lines, red lines signified connections reported in Survey 2 and blue lines indicated connections reported in Survey 3. 
Table 3. Overview of participants (i.e., "nodes") that changed definitions of social values, including their background, definition of social values and social interactions measured by question-answer exchanges (QAEs)

\begin{tabular}{|c|c|c|c|c|c|c|c|c|c|}
\hline & \multicolumn{2}{|c|}{ Background } & \multicolumn{3}{|c|}{ Definition of social values } & \multicolumn{4}{|c|}{ Social interaction } \\
\hline & Discipline & $\begin{array}{l}\text { Years in } \\
\text { field }\end{array}$ & $\begin{array}{l}\text { Level of } \\
\text { operation(s) }\end{array}$ & Mechanism & Outcome & $\begin{array}{l}\text { Cognitive } \\
\text { QAEs }\end{array}$ & $\begin{array}{l}\text { Relational } \\
\text { QAEs }\end{array}$ & $\begin{array}{l}\text { Epistemic } \\
\text { QAEs }\end{array}$ & Change \\
\hline Node 1 & $\begin{array}{l}\text { Psychology } \\
\text { and health }\end{array}$ & $<1$ & Group & $\begin{array}{l}\text { Similar } \\
\text { experience }\end{array}$ & $\begin{array}{l}\text { Changed thought and } \\
\text { practice }\end{array}$ & 0 & 0 & 2 & Clarified term(s) \\
\hline Node 2 & Economics & $10+$ & Group & $\begin{array}{l}\text { Social } \\
\text { context }\end{array}$ & Not applicable & 3 & 0 & 0 & Increased pluralism \\
\hline Node 3 & $\begin{array}{l}\text { Environmental } \\
\text { science }\end{array}$ & $1-3$ & Individual & $\begin{array}{l}\text { Social } \\
\text { context }\end{array}$ & $\begin{array}{l}\text { Changed thought and } \\
\text { practice }\end{array}$ & 8 & 0 & 2 & $\begin{array}{l}\text { Deepened } \\
\text { understanding }\end{array}$ \\
\hline $\begin{array}{l}\text { Mode } \\
\text { (other } \\
\text { nodes) }\end{array}$ & $\begin{array}{l}\text { Economics, } \\
\text { Other Social } \\
\text { Sciences } \\
\end{array}$ & $\begin{array}{l}10+ \\
(\mathrm{M}=5.3)\end{array}$ & Group & $\begin{array}{l}\text { Social } \\
\text { context }\end{array}$ & $\begin{array}{l}\text { Changed thought and } \\
\text { practice, coexistence, } \\
\text { meeting needs }\end{array}$ & 52 & 13 & 15 & Not applicable \\
\hline
\end{tabular}


On average, each workshop participant was involved in 2.5 collaborations during the time period studied. When excluding isolated nodes, the average node degree increased to 3.5 , and the remaining non-isolated nodes had a clustering coefficient of 0.37 . Overall, the network showed a situation in which new individuals were added to the network directly after the workshop (i.e., red lines), while most of the changes that took place after three months (i.e., blue lines) resulted in new connections between individuals that already had strong ties to the network. The three individuals that changed their definitions of social values occupied different positions in the network. One individual (Node 1), formed a single new connection to the network, another (Node 2) did not have any ongoing collaborations before the workshop but connected to multiple other people, and the third (Node 3) did not form any new connections. The "Other Social Sciences" categorization of participants' disciplines was the only grouping that was not represented among the three individuals that changed their definition of social values. Two of the individuals that changed their definition had worked with issues of sustainability less than three years, while those who did not change their definitions had worked with issues of sustainability more than 10 years on average. The original definitions of social values among the three nodes varied, but the observed changes led to an increased correspondence with the most commonly held definitions within the network as a whole. In each of the three cases, the changes in definitions involved clarification or broadening of an existing concept, rather than a complete shift of conceptualization. 


\section{Discussion}

This article advanced an ongoing dialogue in the sustainability science literature focused on how social learning can be conceptualized and measured (Fischer et al., 2014; Reed et al., 2010). Drawing on mixed methods including a longitudinal survey, deliberative workshop and social network analysis, we examined the interconnectedness of individuals in relation to their social interactions within an academic workshop focused on deliberation around social values and sustainability (Raymond et al., 2018). Through this form of methodological triangulation, we explored how social learning acted as a bridge between the individual and a collective in the context of deliberation, while also contributing new knowledge from a social network analysis.

We investigated the role of social capital and social learning in achieving a common definition for the concept of social values among individuals and across a research network. By examining how social capital developed over time and analyzing the stages at which connections were made (i.e., before, immediately after, and long after the workshop), we provided insight on the role of strong ties in social learning outcomes (Burt, 2004; McPherson \& Smith-Lovin, 1987). In other words, we examined the connectedness of individuals in relation to their social interactions during deliberation to better understand the role of social capital and social learning for transformative change. Our results demonstrated how social learning promoted through an academic exchange could lead to a more nuanced understanding of social values and improved interconnectivity among people (Bentley Brymer et al., 2018). Our research underlines the importance of pre-existing connections within a group and variation in knowledge among group members as factors that shape learning processes and outcomes. However, it is important to note that our work is based on a small sample size, which presents challenges for disentangling our 
23 multiple explanatory variables (i.e., discipline, experience, network centrality) and drawing

24 generalizable conclusions without further study.

26 Definitions of social values

27 Our first objective was to document variation and change in definitions of social values

28 among experts before, during and after their participation in a deliberative workshop. The majority of workshop participants described social values as a concept that operated at a collective level and worked through mechanisms of either social relationships or social context.

The outcomes of such mechanisms through which social values formed or evolved were

32 described as "changes in thoughts and practice," "the creation of a common understanding," and

33 "meeting societal needs." However, while some participants developed a more nuanced understanding of social values over the course of the workshop, collectively there was no general agreement among participants on how to define or operationalize social values.

37 academic fields. The Economics and Environmental Science subgroups were more likely to 38 focus on benefits and outcomes from deliberation, while Other Social Scientists placed greater 39 weight on process. This pattern echoes findings in extant literature suggesting that both social 40 values and social learning are contingent on social context and relationships (Diduck et al., 2019; 41 Rodela, 2011, 2013; van Riper et al., 2018; Wegner, 1999). We also found a divide in the views

42 on what outcomes where necessary for something to be regarded a social value between 43 academic disciplines focused on individuals (e.g., psychology, economics) and groups (e.g., 44 sociology, anthropology). Participants from fields focused on group or societal dynamics had a 45 greater tendency to make normative claims in the outcomes of social values research (also see 
46 Kenter et al., 2019), often equating social values with pro-social activity, and adding a

47 requirement of societal improvement (McCrum et al., 2009), or the development of a mutual

48 understanding of concepts (Kulundu, 2012; Armitage et al., 2008). This finding bolsters a trend

49 which is particularly pronounced in literature on applied discursive democracy (Dryzek, 1990),

50 including stakeholder involvement and adaptive management (Plieninger et al., 2013; van Riper

51 et al., 2012) where group processes are devised as a means to achieve increased ecological

52 sustainability (Cundhill \& Rodela, 2012; Muro \& Jeffrey, 2008; Reed, 2010). These perspectives

53 highlight the importance of deliberative social learning as a transformative process to bridge the

54 gap between self-regarding individual values and shared social values that seek to address

55 longer-term societal sustainability concerns (Kenter, 2016; Irvine et al., 2016; Ravenscroft, 56 2019)

57

Question-answer exchanges as social interactions among workshop participants

Examining the social interactions of respondents during the workshop, we found that

60

61

62

63

64

65

66

67

68

cognitive question-answer exchanges were the most common (63), followed by epistemic (19)

and relational learning (13). The prevalence of cognitive question-answer exchanges may have

been related to the nature of the workshop, given that it was centered on technical definitions of

social values. For the three participants who reported a change to their definition of social values,

cognitive changes in understanding were most common. Interestingly, none of these three

participants engaged in relational question-answer exchanges, meaning their experience of the

deliberative workshop did not include changes in relational understanding. Yet, two of the three

participants had no connections to the group prior to the workshop and reported new connections

with at least one other workshop participant in Survey 2. In other words, some participants 
69 identified opportunities to collaborate after the conclusion of the deliberative workshop. This

70 finding underscores the importance of longitudinal research and social network analysis to more

71 effectively capture new or strengthened ties within a network given the implications for

72 understanding social learning and relational values.

$74 \quad$ Social learning, definitions of social values, and social interactions

Participants that had previous collaborations with others were, in general, part of more question-answer exchanges than less well-connected participants. This pattern could be the result

77 of more well-connected individuals having more information to share with the group. However,

78 it could also be resulting from more well-connected individuals having higher trust in the group,

79 and therefore feeling freer to express themselves as suggested by Pretty and Ward (2001) and

80 Granovetter (1973).

81 In relation to the third study objective, we found evidence of three instances of learning

82 related to the reported definitions of social values. The three individuals that changed their

83 definitions all had some connections to the network after the final survey. The growth in the

84 number of collaborations between nodes that already had collaborations between Survey 2 and

85 Survey 3 indicated that these strong ties contributed to within group trust building, while the lack

86 of change in definitions also indicated these individuals were less likely to be exposed to new

87 ideas (Prell et al., 2009). Conversely, weak ties indicated a propensity to be more open to

88 changes in definitions (Fischer et al., 2014), possibly due to a combination of receiving new

89 information and alignment of existing definitions with group-level norms. Thus, our results lend

90 some support to literature that engages social capital theory and social network analysis that 
91 suggests group interactions and similarities of definitions of social values contribute to social

92 learning (Burt, 2004; McPherson \& Smith-Lovin, 1987).

Workshop participants that were engaged in a deliberative exchange about social values

94 for sustainability experienced different levels of learning. A majority of participants showed

95 indications of incremental improvement in their knowledge that did not involve questioning the

96 underlying assumptions of an idea (i.e., single-loop learning (Reed et al., 2010)), while not

97 challenging the assumptions behind what we learn (i.e., double loop learning), or questioning the

98 notion of what it means to learn (i.e., triple loop learning) (Argyris \& Schön, 1978; Pahl-Wostl et

99 al., 2008). Most often, surface-level signs of change in social learning conformed towards

100 knowledge that was strongly held by other similar members of the group, possibly indicating an

101 existence of a homophily effect (McPherson, \& Smith-Lovin, 1987). The weak ties that

102 connected participants in a loosely connected network were important for learning (Levin \&

103 Cross, 2004), as were the strong ties that facilitated trust and more transformative learning from

104 self-reflection (Bentley Brymer et al., 2018). We also observed that changes in definitions were

105 reported by individuals who had been working with issues of social values in sustainability a

106 comparably short amount of time. This may explain why the Other Social Science subgroup was

107 less likely to change their definitions of social values given the potential for more experience

108 working with conceptual frameworks than participants working in the natural sciences.

110 Conclusion

This article showcases a mixed methods research approach to measure social learning

112 through social network analysis, qualitative analysis of deliberation and a longitudinal survey

113 design. In addition to demonstrating the potential of social network analysis as a tool to 
114 understand social learning in the context of social values for sustainability, our empirical results 115 also offer a number of interesting contributions to the literature. We indicate, not unintuitively, 116 that social learning occurs where individuals holding a less well developed understanding of a 117 concept engage with more elaborate knowledge that is accepted by other individuals within a 118 social context. More generally, our results highlight the plurality of multiple understandings of 119 social values that exist within the sustainability sciences (also see Kenter et al., 2019) and 120 suggest that epistemic and conceptual plurality do not necessarily prevent social learning from 121 taking place. Building on this work, future research within sustainability science should continue 122 to strive towards a more refined understanding of individual and group level dynamics involved 123 in social learning, as well as better understand the role, potential and limitations of social 124 learning in deliberative decision-making for environmental management and policy making. 125 126 


\section{References}

Argyris, C., \& Schön, D.A. (1978). Organizational learning: A theory of action perspective. Reading, MA: Addison-Wesley Pub. Co.

Armitage, D., Berkes, F., Dale, A., Kocho-Schellenberg, E., \& Patton, E. (2011). Comanagement and the co-production of knowledge: Learning to adapt in Canada's Arctic. Global Environmental Change, 21(3), 995-1004.

Armitage, D., Marschke, M., \& Plummer, R. (2008). Adaptive co-management and the paradox of learning. Global Environmental Change, 18(1), 86-98.

Bandura, A. (1977). Social learning theory. Englewood Cliffs, NJ: Prentice Hall.

Bandura, A. (2018). Toward a psychology of human agency: Pathways and reflections. Perspectives on Psychological Science, 13(2), 130-136.

Barber, W.F., \& Bartlett, R.V. (2005). Deliberative environmental politics: Democracy and ecological rationality. MIT Press, Cambridge, MA.

Bentley Brymer, A.L., Wulfhorst, J.D., \& Brunson, M.W. (2018). Analyzing stakeholders' workshop dialogue for evidence of social learning. Ecology and Society, 23(1), 42.

Berkes, F. (2009). Evolution of co-management: Role of knowledge generation, bridging organizations and social learning. Journal of environmental management, 90(5), 16921702.

Bourdieu, P. (1986). The forms of capital. In: Handbook of theory and research for the sociology of education, J. G. Richardson, Ed. (pp. 241-58). New York: Greenwood Press.

Brown, T.C. (1984). The concept of value in resource allocation. Land economics, 60(3), 231246.

Brown, G., \& Kyttä, M. (2014). Key issues and research priorities for public participation GIS (PPGIS): A synthesis based on empirical research. Applied geography, 46, 122-136

Burt, R.S. (2004). Structural holes and good ideas. American Journal of Sociology, 110(2), 349399.

Cash, D.W., Clark, W.C., Alcock, F., Dickson, N.M., Eckley, N., Guston, D.H., ... \& Mitchell, R.B. (2003). Knowledge systems for sustainable development. Proceedings of the national academy of sciences, 100(14), 8086-8091.

Chan, K.M., Gould, R. K., \& Pascual, U. (2018). Editorial overview: Relational values: what are they, and what's the fuss about?.

Chan, K.M., Guerry, A.D., Balvanera, P., Klain, S., Satterfield, T., Basurto, X., ... \& Hannahs, N. (2012). Where are cultural and social in ecosystem services? A framework for constructive engagement. BioScience, 62(8), 744-756.

Chan, K. M., Balvanera, P., Benessaiah, K., Chapman, M., Díaz, S., Gómez-Baggethun, E., ... \& Luck, G. W. (2016). Opinion: Why protect nature? Rethinking values and the environment. Proceedings of the National Academy of Sciences, 113(6), 1462-1465.

Collins, K., \& Ison, R. (2009). Jumping off Arnstein's ladder: social learning as a new policy paradigm for climate change adaptation. Environmental Policy and Governance, 19(6), 358-373.

Culwick, C., Washbourne, C L., Anderson, P.M., Cartwright, A., Patel, Z., \& Smit, W. (2019). CityLab reflections and evolutions: Nurturing knowledge and learning for urban sustainability through co-production experimentation. Current Opinion in Environmental Sustainability, 39, 9-16. 
Cundill, G., \& Rodela, R. (2012). A review of assertions about the processes and outcomes of social learning in natural resource management. Journal of Environmental Management, $113,7-14$.

Daniell, K.A., White, I., Ferrand, N., Ribarova, I. S., Coad, P., Rougier, J.E., ... \& Perez, P. (2010). Co-engineering participatory water management processes: Theory and insights from Australian and Bulgarian interventions. Ecology and Society, 15(4), 11.

Diduck, A. P., Raymond, C.M., Rodela, R., Moquin, R., \& Boerchers, M. (2019). Pathways of learning about biodiversity and sustainability in private urban gardens. Journal of Environmental Planning and Management, 1-21.

Dietz, T. (2013). Bringing values and deliberation to science communication. Proceedings of the National Academy of Sciences, 110(Supplement 3), 14081-14087.

Dietz, T., Ostrom, E., \& Stern, P. C. (2003). The struggle to govern the commons. Science, 302(5652), 1907.

Dietsch, A.M., Teel, T.L., \& Manfredo, M.J. (2016). Social values and biodiversity conservation in a dynamic world. Conservation Biology, 30(6), 1212-1221.

Dryzek, J.S. (1990). Discursive democracy: Politics, policy, and political science. New York: Cambridge University Press.

Fischer, A. P., Vance-Borland, K., Burnett, K. M., Hummel, S., Creighton, J. H., Johnson, S. L., \& Jasny, L. (2014). Does the social capital in networks of "fish and fire" scientists and managers suggest learning? Society \& Natural Resources, 27(7).

Folke, C., Hahn, T., Olsson, P., \& Norberg, J. (2005). Adaptive governance of social-ecological systems. Annu. Rev. Environ. Resour,30(1), 441-73

Frantzeskaki, N., \& Kabisch, N. (2016). Designing a knowledge co-production operating space for urban environmental governance-Lessons from Rotterdam, Netherlands and Berlin, Germany. Environmental Science \& Policy, 62, 90-98.

Goodin, R.E. (2017). The epistemic benefits of deliberative democracy. Policy Sciences, 351366.

Goodin, R.E., \& Niemeyer, S.J. (2003). When does deliberation begin? Internal reflection versus public discussion in deliberative democracy. Political Studies 51, 627-649.

Gould, R., Pai, M., Chan, K., \& Muraca, B. (2019). How one indigenous worldview informs relational values and social values. Sustainability Science.

Grainger, D., \& Stoeckl, N. (2019). The importance of social learning for non-market valuation. Ecological Economics, 164, 106339.

Granovetter, M.S. (1973). The strength of weak ties. American Journal of Sociology, 78(6), 1360-1380.

Graesser, A.C., Langston, M.C., \& Baggett, W.B. (1993). Exploring information about concepts by asking questions. Psychology of Learning and Motivation, 29, 411-436.

Graesser, A.C., Li, H., \& Forsyth, C. (2014). Learning by communicating in natural language with conversational agents. Current Directions in Psychological Science, 23, 374-380.

Guest, G., Namey, E.E., \& Mitchell, M.L. (2012). Collecting qualitative data: A field manual for applied research. Sage.

Hahn, T., Schultz, C., Folke, C., \& Olsson, P. (2008). Social networks as sources of resilience in social-ecological systems. In J. Norberg \& G. Cumming (Eds.), Complexity theory for a Sustainable Future. Columbia University Press. 
Irvine, K.N., O’Brien, L., Ravenscroft, N., Cooper, N., Everard, M., Fazey, I., ... \& Kenter, J.O. (2016). Ecosystem services and the idea of shared values. Ecosystem Services, 21, 184193.

Kates, R.W., Clark, W.C., Corell, R., Hall, J.M., Jaeger, C.C., Lowe, I., ... \& Faucheux, S. (2001). Sustainability science. Science, 292(5517), 641-642.

Kendal, D., \& Raymond, C. (2019). Understanding pathways to shifting values over time in the context of social-ecological systems. Sustainability Science.

Kenter, J.O. (2016). Shared, plural and cultural values. Ecosyst. Serv, 21, 175-183.

Kenter, J.O., O'Brien, L., Hockley, N., Ravenscroft, N., Fazey, I., Irvine, K.N., ... \& Church, A. (2015). What are shared and social values of ecosystems?. Ecological Economics, 111, 86-99.

Kenter, J.O., Reed, M.S., \& Fazey, I. (2016a). The deliberative value formation model. Ecosystem Services, 21, 194-207.

Kenter, J.O., Bryce, R., Christie, M., Cooper, N., Hockley, N., Irvine, K.N., ... \& Raymond, C. M. (2016). Shared values and deliberative valuation: Future directions. Ecosystem services, 21, 358-371.

Kenter, J.O., Raymond, C., van Riper, C.J., Azzopardi, E., Brear, M.R., Calcagni, F., Christie, I., Chrisite, M., Gould, R.K., Ives, C.D., Hejnowicz, A.P., Gunton, R., Horcea-Milcu, A., Kendal. D., Kronenberg, J., Massenberg, J.R., O’Connor, S., Ravenscroft, N., Raymond, I.J., Rawluk, A., \& Rodríguez-Morales, J. (2019). Loving the mess: Navigating diversity and conflict in social values for sustainability. Sustainability Science.

Kulundu, I. (2012). In pursuit of participation: tracking the influence of local action for sustainable development. Lotz-Sisitka, HB (ed.). Views on Social Learning Literature: A monograph for social learning researchers in natural resources management and environmental education, Environmental Learning Research Centre, Rhodes University/EEASA/SADC REEP, Grahamstown.

Levin, D. Z., \& Cross, R. (2004). The strength of weak ties you can trust: The mediating role of trust in effective knowledge transfer. Management Science, 50(11), 1477-1490.

Liu, J., Dietz, T., Carpenter, S. R., Alberti, M., Folke, C., Moran, E., ... \& Ostrom, E. (2007). Complexity of coupled human and natural systems. science, 317(5844), 1513-1516.

Lundmark, C., Matti, S., \& Sandström, A. (2014). Adaptive co-management: How social networks, deliberation and learning affect legitimacy in carnivore management. European journal of wildlife research, 60(4), 637-644.

Manfredo, M.J., Bruskotter, J.T., Teel, T.L., Fulton, D., Schwartz, S.H., Arlinghaus, R., ... \& Sullivan, L. (2017). Why social values cannot be changed for the sake of conservation. Conservation Biology, 31(4), 772-780.

Marshall, C., \& Rossman, G.B. (2006). Designing qualitative research. Sage Publications, Inc., Thousand Oaks, CA.

McCrum, G., Blackstock, K., Matthews, K., Rivington, M., Miller, D., \& Buchan, K. (2009). Adapting to climate change in land management: The role of deliberative workshops in enhancing social learning. Environmental Policy \& Governance, 19(6), 413-426.

McPherson, J. M., \& Smith-Lovin, L. (1987). Homophily in voluntary organizations: Status distance and the composition of face-to-face groups. American Sociological Review, 52(3), 370-379. 
Medema, W., Furber, A., Adamowski, J., Zhou, Q., \& Mayer, I. (2016). Exploring the potential impact of serious games on social learning and stakeholder collaborations for transboundary watershed management of the St. Lawrence River Basin. Water, 8(5), 175.

Merriam, B.S., \& Caffarella, S.R. (1998). Learning in adulthood. A comprehensive guide, 2nd ed. Jossey-Bass Publishers, San Francisco.

Muro, M., \& Jeffrey, P. (2008). A critical review of the theory and application of social learning in participatory natural resource management processes. Journal of Environmental Planning and Management, 51(3), 325-344.

Ostrom, E. (1990). Governing the commons: The evolution of institutions for collective action. New York: Cambridge University Press.

Ostrom, E. (2009). A general framework for analyzing sustainability of social-ecological systems. Science, 325(5939), 419-422.

Pahl-Wostl, C., Craps, M., Dewulf, A., Mostert, E., Tabara, D., \& Taillieu, T. (2007). Social learning and water resources management. Ecology and society, 12(2).

Pahl-Wostl, C., Tàbara, D., Bouwen, R., Craps, M., Dewulf, A., Mostert, E., . . Taillieu, T. (2008). The importance of social learning and culture for sustainable water management. Ecological Economics, 64(3), 484-495.

Pascual, U., Balvanera, P., Díaz, S., Pataki, G., Roth, E., Stenseke, M., ... \& Maris, V. (2017). Valuing nature's contributions to people: the IPBES approach. Current Opinion in Environmental Sustainability, 26, 7-16.

Pellizzoni, L. (2001). The myth of the best argument: Power, deliberation and reason. British Journal of Sociology 52, 59-86

Plieninger, T., Dijks, S., Oteros-Rozas, E., \& Bieling, C. (2013). Assessing, mapping, and quantifying cultural ecosystem services at community level. Land use policy, 33, 118129.

Prell, C., Hubacek, K., \& Reed, M. (2009). Stakeholder analysis and social network analysis in natural resource management. Society \& Natural Resources, 22(6), 501-518.

Pretty, J., \& Ward, H. (2001). Social capital and the environment. World Development, 29(2), 209-227.

Putnam, R.D. (2000). Bowling alone: America's declining social capital. In Culture and politics (pp. 223-234). Palgrave Macmillan, New York.

Rawluk, A., Ford, R., Anderson, N., \& Williams, K. (2019). Exploring multiple dimensions of values and valuing: A conceptual framework for mapping and translating values for social-ecological research and practice. Sustainability Science.

Reed, M. S., Evely, A. C., Cundill, G., Fazey, I., Glass, J., Laing, A., . . Stringer, L. C. (2010). What is social learning? Ecology and Society, 15(4).

Raymond, C. M., Kenter, J. O., Plieninger, T., Turner, N. J., \& Alexander, K. A. (2014). Comparing instrumental and deliberative paradigms underpinning the assessment of social values for cultural ecosystem services. Ecological Economics, 107, 145-156.

Raymond, C. M., \& Kenter, J. O. (2016). Transcendental values and the valuation and management of ecosystem services. Ecosystem Services, 21, 241-257.

Raymond, C.M., Kenter, J.O., Kendal, D., van Riper C.J., \& Rawluk, A. (2018). Call for papers for "Theoretical traditions in social values for sustainability." Sustainability Science, 13(2), 269-271.

Ravenscroft, N. (2019). A new normative economics for the formation of shared social values. Sustainability Science, 1-11. 
Reich, R.B. (1985). Public administration and public deliberation: An interpretive essay. Yale Law J. 94(7), 1617-1641.

Reyers, B., Nel, J.L., O’Farrell, P.J., Sitas, N., \& Nel, D.C. (2015). Navigating complexity through knowledge coproduction: Mainstreaming ecosystem services into disaster risk reduction. Proceedings of the National Academy of Sciences, 112(24), 7362-7368.

Rist, S., Chidambaranathan, M., Escobar, C., Wiesmann, U., \& Zimmermann, A. (2007). Moving from sustainable management to sustainable governance of natural resources: The role of social learning processes in rural India, Bolivia and Mali. Journal of rural studies, 23(1), 23-37.

Rodela, R. (2011). Social learning and natural resource management: The emergence of three research perspectives. Ecology and Society, 16(4).

Rodela, R. (2013). The social learning discourse: Trends, themes and interdisciplinary influences in current research. Environmental Science \& Policy, 25, 157-166.

Rokeach, M. (1973). The nature of human values. Free Press, New York

Schwartz, S.H. (1994). Are there universal aspects in the structure and contents of human values?. Journal of social issues, 50(4), 19-45.

Schroeder, H. (2013). Sensing value in place. In: W. Stewart, D. Williams, \& L. Kruger (Eds.), Place-based conservation: Perspectives from the social sciences (pp. 131-155). Dordrecht, The Netherlands: Springer.

Schusler, T. M., Decker, D. J., \& Pfeffer, M. J. (2003). Social learning for collaborative natural resource management. Society \& natural resources, 16(4), 309-326.

Scott, J. Social network analysis. Sociology 22.1 (1988): 109-127.

Steyaert, P., \& Jiggins, J. (2007). Governance of complex environmental situations through social learning: a synthesis of SLIM's lessons for research, policy and practice. Environmental Science \& Policy, 10(6), 575-586.

Umemoto, K., \& Suryanata, K. (2006). Technology, culture, and environmental uncertainty: Considering social contracts in adaptive management. Journal of Planning Education and Research, 25(3), 264-274.

van Riper C.J., \& Kyle, G.T. (2014). Capturing multiple values of ecosystem services shaped by environmental worldview: A spatial analysis. Journal of Environmental Management, 145, 374-384.

van Riper, C.J., Thiel, A., Penker, M., Braito, M., Landon, A.C., Thomsen, J., \& Tucker, C.M. (2018). Incorporating multi-level values into the social-ecological systems framework. Ecology and Society, 23(3), 25.

van Riper, C.J., Kyle, G.T., Sutton, S.G., Barnes, M., \& Sherrouse, B.C. (2012). Mapping outdoor recreationists' perceived social values for ecosystem services at Hinchinbrook Island National Park, Australia. Applied Geography, 35(1-2), 164-173.

van Riper, C.J., Winkler-Schor, S., Stamberger, L., Keller, R., Braito, M., Raymond, C., Eriksson, M., Golebie, E., \& Johnson, D. (2019). Integrating multi-level values and proenvironmental behavior in a protected area. Sustainability Science.

Vinke-de Kruijf, J., \& Pahl-Wostl, C. (2016). A multi-level perspective on learning about climate change adaptation through international cooperation. Environmental Science \& Policy, 66, 242-249.

Wal, M., De Kraker, J., Offermans, A., Kroeze, C., Kirschner, P. A., \& Ittersum, M. (2014). Measuring social learning in participatory approaches to natural resource management. Environmental Policy and Governance, 24(1), 1-15. 
351 Webler, T., Kastenholz, H. \& Renn, O. (1995). Public participation in impact assessment: A 352 social learning perspective. Environmental Impact Assessment Review 15:443-463.

353 Wenger, E. (1999). Communities of practice: learning, meaning, and identity. Cambridge $354 \quad$ University Press, Cambridge, UK. 